\title{
SWOT PRINCIPLE IN FLOOD RISK MANAGEMENT
}

\author{
Vasile Gramaํ, ORCID ID: 0000-0002-2100-2756, \\ Agostino Avanzi i*, ORCID ID: 0000-0003-1426-9337, \\ Livia Nistor-Lopatenco ${ }^{1}$, 0000-0003-3509-648X \\ ${ }^{1}$ Technical University of Moldova, Stefan cel Mare av. 168, Chisinau, MD-2004 Republic of Moldova \\ ${ }^{2}$ Idrostudi, c/o Area Science Park - Ed. A-M Loc. Padriciano, 99 - 34149 Trieste (TS) - ITALY \\ ${ }^{*}$ Corresponding author: Agostino Avanzi, international@idrostudi.it
}

Received: 27.03 .2021

Accepted: 06.05.2021

\begin{abstract}
An analysis of global statistics shows a substantial increase in flood damage over the past few decades. With the recent transition to a more risk-based approach in European flood management policy, flood analysis models have become an important part of flood risk management. In many cases, flood damages are extensive to the environment, to the economy and also socially. According to the priority development trend "Infrastructure and Environment", Ungheni district of Republic of Moldova (RM) aims for an efficient infrastructure, based on environmental protection, whose development, operation and maintenance will be done using of a database, protocols, existing guides and accessible to the level of each local public administration. In the last decade, projects have been implemented in Moldova to study the phenomenon of floods in order to develop structural and non-structural measures to protect localities. This article aims is to systematize the existing knowledge and characteristics of the methods available to give operational recommendations and principles that can support authorities, local entities, and the stakeholders involved in decision-making with regard to flood risk management in their compliance with the Floods Directive (2007/60/EC), national and local legal framework.
\end{abstract}

Keywords: flood risk, GIS, flood risk management, flood Directive, hydraulic modelling, Flood Risk Assessment (FRA), SWOT analysis.

\section{Introduction}

RM is prone to different kinds of natural hazards including drought, floods, severe weather, earthquakes and landslides. In many cases, flood damages are extensive to the environment, to the economy and also socially. Heavy rains result in frequent floods, to which a great part of the country's settled areas are exposed. The most recent severe floods occurred in 2008, 2010 \& 2020. Climate variability and change is likely to increase the frequency and intensity of natural disasters. Flood risk management aims at mitigating the impact of such extreme events as floods. Important to consider that emergency situations regarding flood can happen not only as result of natural overflow, but also as a result of accidents at hydrotechnical constructions on the rivers. The management of these 
emergency situations generated by floods is more than a necessity considering the frequency of the production and the dimension of those effects. According to the Directive [1], the key-elements for effective flood risk management are:

- damage preventing by avoiding building houses and other buildings in flooded areas;

- taking practical measures for affected areas by floods in order to mitigate their impact;

- informing the population about the being flood risk;

- developing the plans of emergency response in case of floods,

- mitigation the social and economic impact of floods on the affected population.

The historic events of natural hazards on the Republic of Moldova territory was studied by Mihailescu [2], the research confirms that floods on the current territory occur from the oldest times - the first documented events were in 544, 545-547, 895-896, 1007, $1146,1156,1162,1164$ etc. In the XXth century the flood events occurred in 1908, 1911, 1913, 1927, 1932, 1933, 1941, 1948, 1955, 1962, 1969, 1974, 1976, 1979-1981, 1984, 1991, 1993, 1994, 1995, and the most recently events date from 2008, 2010 and 2020 (https://www.facebook.com/ntvmoldova/videos/inunda\%C8\%9Bii-devastatoare-la-

comrat/328029908493119/; https://www.zdg.md/stiri/ stiri-sociale/foto-inundatiile-de-lacomrat-igsu-anunta-ca-a-creat-statul-major-155-de-angajati-lucreaza-la-fata-locului). But, actually, the risk is different from 544 to 1007, from 1007 to 2008, and difference permanently increases. Firstly, because vulnerability is the component that changes overtime and directly depends on the level of economic development of the country and it is appreciated as the most complicated component of the risk assessment process. Secondly, vulnerability concept has a wide range of interpretations and dimensions along multi definitions and different conceptual frameworks [3,4].

Natural hazards are an integral part of everyday life. The multiple studies show that their final elimination is impossible, from which it follows that the main and constant option being to reduce losses via prevention measures, because disaster prevention is always cheaper than subsequent recovery. Flood risk management means the application of policies, procedures and practices aimed at identifying risks, analysing and assessing them, treating, monitoring and reassessing risks, developing and implementing appropriate measures to reduce them, so that human communities, all citizens can live, work and meet the needs and aspirations in a sustainable economical and social environment [5].

In the context of flood protection, the Local Public Authorities, including Ungheni district, are characterized by:

- lack of well, clear and accessible guidelines, protocols for different categories of people for simple application;

- Low standards in building, inappropriate planning of the terrain usage, illegal building of houses in vulnerable areas,

- outdated system of flood control (over 3500 breakwaters and dams require urgent repair in order to cope with such crises situations as from 2015),

- insufficient works with a protection role against floods, the necessity of establishing a flood monitoring system at the national and sub-regional level up to international standards, 
- lack of collaboration between the designing institution „Acvaproiect”, „Urbanproiect”, „Ruralproiect” and the Institute for Design of Auto Road in order to develop some general complex plans of building construction, taking into account protected measures against floods,

- confusions at government level about institutional capacity (responsible institutions, ownership aspect etc.).

The existing situation highlights the need for a detailed SWOT analysis on the study of floods, protection measures and knowledge's at the level of Local Public Authorities (LPA), various stakeholders, including at the level of residents in risk areas. The purpose of this paper is to identify weaknesses and opportunities for local strategies on the risk flood areas in Ungheni district. The data and information collected on this domain refer mainly, to the ones collected under the EPTATF 2013-2016, Management and Technical Assistance Support to Moldova, Flood Protection Project - Service contract No TA2011038 MD EST funded by the EIB [7]. By implementing that project was collected geographic data and information about rivers network and lakes (more than 11,700 very small/small/medium and large) on the whole territory of the RM by digitizing the water surface on orthophoto. The latter one layer was used and processed for hydraulic purposes verifying its consistency with the actual situation on the ground. An assessment of the data quality was also carried out and obtained from the data owner. The result of this assessment was recorded to ensure that data quality is fitting for analyses of flood events.

\section{Legal Framework}

In order to achieve the expected results, it is necessary to identify the national and EU legislative framework with direct or tangential involvement, which would allow the elaboration of the adjustment instruments, as well as the identification of the institution and the human resources responsible for the prevention of the hazards included flood activities and the elaboration of the adjustment instruments on the local legislative framework. At present, the field of water bodies management is regulated by a series of normative acts (laws and Government decisions).

In this light, the concept of managing flood risk has shifted towards exploring more comprehensive and sustainable approaches. This change has been guided by international initiatives and legislation at a European level, such as the European Floods Directive 2007/60/EC [1], is one example. This flood risk management (FRM) vision not only considers hazards, but also possible consequences [6]. The directive prescribes risk assessment and mapping as well as the development of flood risk management plans, aimed at reducing adverse consequences. In order to obtain a good result of environmental studies, especially when it comes to a geographical area located on the border with a country in the European Community, it is necessary to take into account both the EU and national legal framework.

\subsection{International regulatory framework}

The following lists reflect the most relevant International Normative Acts/International agreements which is recommended to take in considerations:

1. EU Water Framework Directive (WFD, 2000/60/EC) which aims to establish a framework for the protection of surface waters and not only their surface waters [8];

2. EU Floods Directive (FD, 2007/60/EC) on the assessment and management of flood risks 
- establishing a framework for the assessment and management of flood risks, with the aim of reducing the negative consequences for human health, environment, cultural heritage and economic activity associated with floods [1];

3. The framework for cooperation with the EU, in force since July 1998;

4. Protocols on Water and Health;

5. The Aarhus Convention The UNECE Convention on Access to Information, Public Participation in Decision-Making and Access to Justice in Environmental Matters was signed on 25 June 1998 and entered into force on 30 October 2001;

6. Millennium Development Goals (MDGs) - Millennium Declaration, UN Millennium Summit, New York, 2000 etc.

\subsection{National regulatory framework}

The first two EU Directives have found their transposition into the Law of Waters, Government Decision no. 590 of 21.06.2018 regarding the approval of the Concept of the reform of the national system of management, prevention and reduction of the consequences of floods. Thus, the transposition of the provisions of Directive 2007/60 / EC and synchronized with the implementation of the Framework Directive 2000/60 / EC on establishing an EU water policy framework, both by coordinating flood risk management plans and river basin management plans, as well as by coordinating public participation procedures in the preparation of these plans. In the following, a series of normative acts with direct implication, either tangential to the purpose of this task, is listed:

1. Water law of 23.12.2011, regulates the legal framework for water management, protection and use (partially harmonized with EU directives in the field of water, including the Framework Directive 2000/60 / EC of the European Parliament and of the Council of 23 October 2000 on the establishment of an EU water policy framework and Directive 2007/60 / EC of the European Parliament and of the Council of 23 October 2007);

2. The Law on Natural Resources no.1102 of 06.02.1997, published in the Official Gazette no. 40 of 19.06.1997, stipulates that all surface waters and groundwater are national water resources and the first impermeable layer local resource;

3. Law on Environmental Protection no. 1515-XII of 16.06.1993, published in the Official Gazette no. 10/283 of 30.10 .1993 establishes the framework for the protection of all water resources and aquatic ecosystems;

4. The Law on Areas and Strips for Protection of Rivers and Aquatic Basins No. 440 of April 27, 1995, published in the Official Gazette no. 43 of 03.08.1995, establishes the requirement to create protection zones and strips along the rivers and bodies and regulates related activities;

5. Law no. 271-XIII of 9 November 1994 on civil protection, establishes the fundamental principles of organizing civil protection in the Republic of Moldova, which is a system of measures and actions taken to ensure the protection of the population, property in natural and ecological calamities, disasters;

6. Law no.721 of 02.02.1996 on quality in constructions - establishes the legal, technical, economic and organizational basis of activity of physical and juridical persons in the field of constructions, their obligations and their responsibility regarding the quality in constructions;

7. The Government Decision no.977/2016 regarding the approval of the Regulation for the 
exploitation of the accumulation lakes/ponds, which regulates the way of drawing up the Regulation of the accumulation lakes/ponds and establishes the general criteria for the exploitation of the water accumulations, regardless of the form of property, for the purpose of their fair and sustainable exploitation, and applies to any natural or legal person who owns and manages accumulation lakes/ponds;

8. Government Decision No.590 of 21.06.2018 on the approval of the Concept of Reform of the National System for Flood Management, Prevention and Reduction - the purpose of the Concept is to establish fundamental principles and objectives for flood protection as well as to adjust the legal framework and institutional management in the field of flood risk management, prevention and reduction;

9. 9.10. Government Decision on approval of the Water State Cadastre Regulation No. 763 of 23.09.2013, published in the Official Gazette no. 213-215 of 27.09.2013 establishes the structure and content of the State Water Cadastre, and the purpose of the Cadaster is the efficient management, protection and use of surface waters and groundwater on the basis of state evidence of cadastral data and the provision of central public authorities, local public administration authorities, natural and legal entities interested in cadastral information;

10. Government Decision no. 1030 of October 13, 2000 "On the approval of the Protection Scheme of the Republic of Moldova against floods" provides for the primary measures to protect the localities and flood land, as well as to counteract the negative consequences on the national economy and on the environment;

11. Government Decision no. 433 of June 18, 2012 "For the approval of the Regulation on flood protection dams", establishes mandatory provisions for the application of all natural and legal persons involved in the design, construction and exploitation of flood protection dams located in the Republic of Moldova;

12. Government Decision no. 887 of 11 November 2013 "On the approval of the Flood Risk Management Regulation" (partly transposed by Directive 2007/60 / EC of the European Parliament and of the Council of 23 October 2007 on the assessment and management of flood risks) sets out the regulatory framework for risk management floods based on flood risk management plans in river basins, procedures and assistance mechanisms for the population affected by floods;

13. Govermmanet Decision (G.D.) Nr. 562/2020, approved the Flood risk management plan for the Danube-Prut and Black Sea river basin district (figure 1).

The structure of the National Flood Warning, Alarm and Response System for Flood Risk Reduction involves four stages of action:

1. monitoring,

2. forecasting and prevention,

3. warning,

4. response to floods by eliminating the consequences.

The main source for developing Action Plan (for example, the sequence in the table 1 ) is the EPTATF 2013-2016, project [7]. Legislative acts clearly reflect the main notions relevant to the field of floods such as:

Floods are natural phenomena which cannot be prevented. 


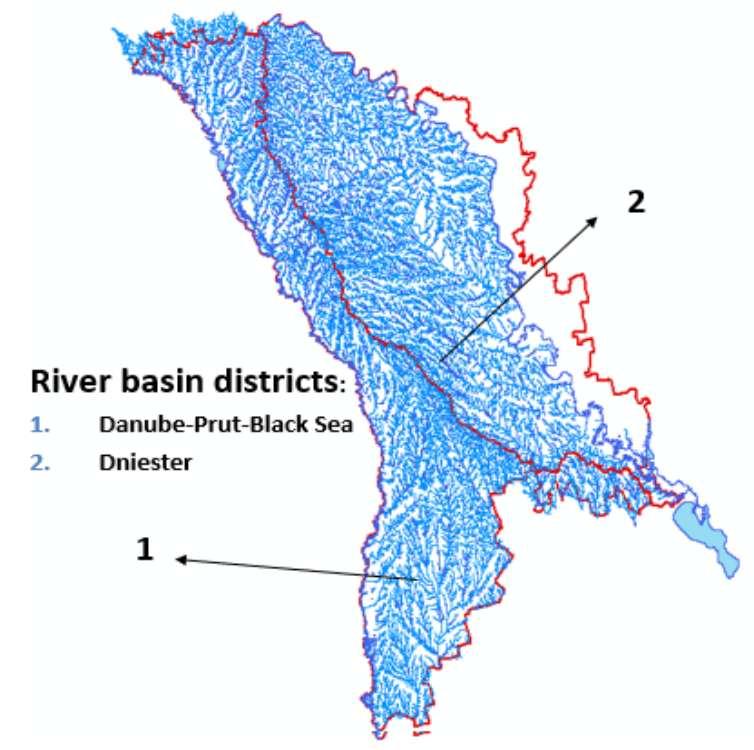

Figure 1. Hydrographic basin districts of RM.

However, some human activities (such as increasing human settlements and economic assets in floodplains and the reduction of the natural water retention by land use) and climate change contribute to an increase in the likelihood and adverse impacts of flood events. Flood means the temporary covering by water of land not normally covered by water. This shall include floods from rivers, mountain torrents, Mediterranean ephemeral water courses, and floods from the sea in coastal areas, and may exclude floods from sewerage systems;

Flood risk - means the combination of the probability of a flood event and of the potential adverse consequences for human health, the environment, cultural heritage and economic activity associated with a flood event.

Table 1

The sequence from the G.D. Nr. 562/2020

\begin{tabular}{|c|c|c|c|}
\hline Nr. & District & $\begin{array}{l}\text { Name of areas } \\
\text { (location) }\end{array}$ & General assessment of conditions \\
\hline P5 & Ungheni & $\begin{array}{l}\text { Flooded areas near } \\
\text { Sculeni }\end{array}$ & $\begin{array}{l}\text { Unsatisfactory condition: the ridge of the } \\
\text { dam is uneven, unevenness of } 0.5-0.7 \mathrm{~m} \text {; } \\
\text { risk of overflow for } 5 \% \text { of the total length of } \\
\text { the dam. }\end{array}$ \\
\hline
\end{tabular}

Areas with a potentially significant risk of flooding were identified on the basis of the preliminary flood risk assessment, which was carried out within the project EPTATF 2013-2016 [7]. The methodology for developing of the Master Plan for flood risk management planning according the EU Floods Directive [2007/60/EC], include the follow cycle $[8,9]$ :

1. Identifying flood hazard and risk areas,

2. Identifying measures to reduce flood risk,

3. Developing a Phased Investment Programm,

4. Strengthening the capacity of the responsable institutions. 


\section{Data colection for the flood risk management}

High level hydrological and hydraulic modelling carried out for $12000 \mathrm{~km}$ of rivers to identify the areas with highest flood risks according of the methodology involve:

- estimated $1 \%$ flood modelled in order to identify flood prone area,

- vulnerability assessment defines the relationship between flood characteristics and damage,

- flooded areas overlapped with vulnerability to produce flood risk map (figure 2).
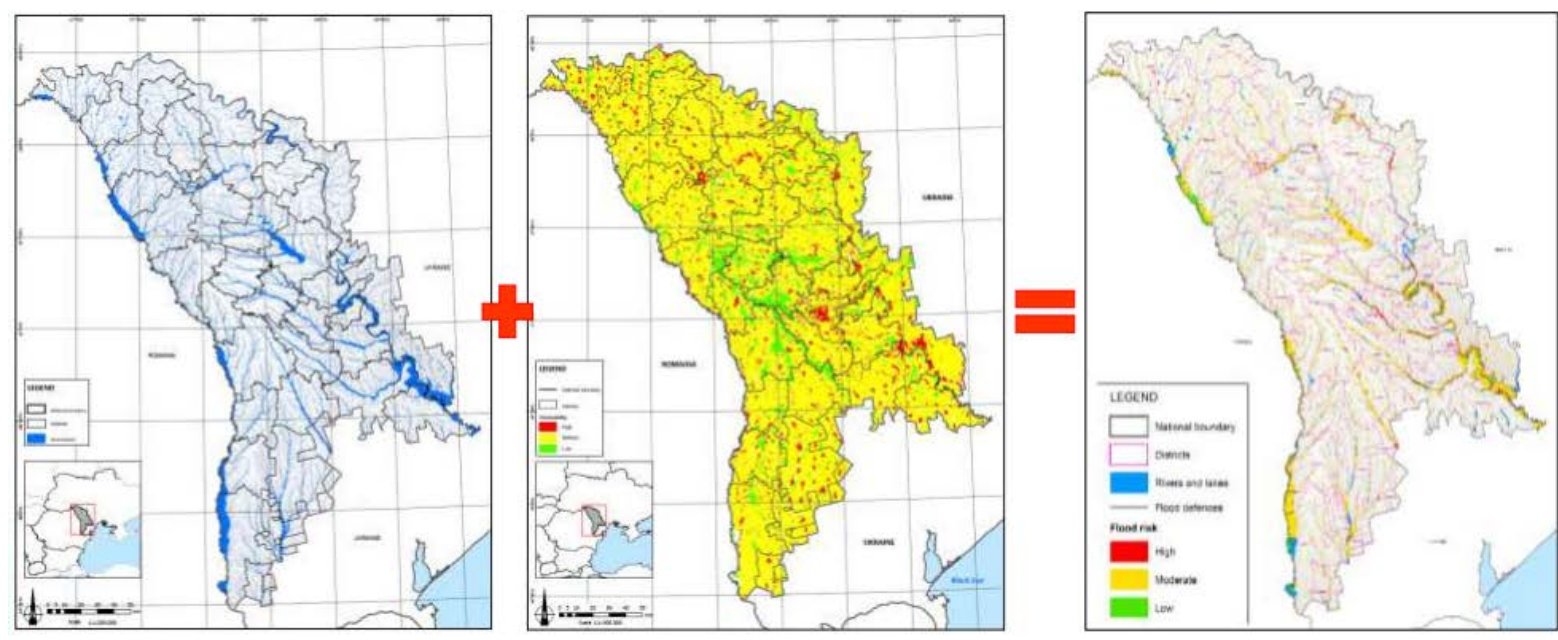

Figure 2. Graphical interpretation of the process for creation of the risk maps.

For detailed hydraulic modelling the data collection include about the 743 cross sections surveyed (river channel bathymetry) on Prut (including Costești-Stânca reservoir) and the 15,700 dykes crest levels points surveyed (dykes condition evaluated and 12,700) georeferred pictures taken and the results is reflected in a GIS layer indicating the dyke satisfactory/poor condition [10]. For geographic data collection, airborne laser scanning technology on $1,912 \mathrm{~km}^{2}$, with resolution $2 \mathrm{p} / \mathrm{m}^{2}$ (figure 3) was used.

Essential for planning system improvements was people interviews to collect knowledge of rivers and flood defenses condition [7].
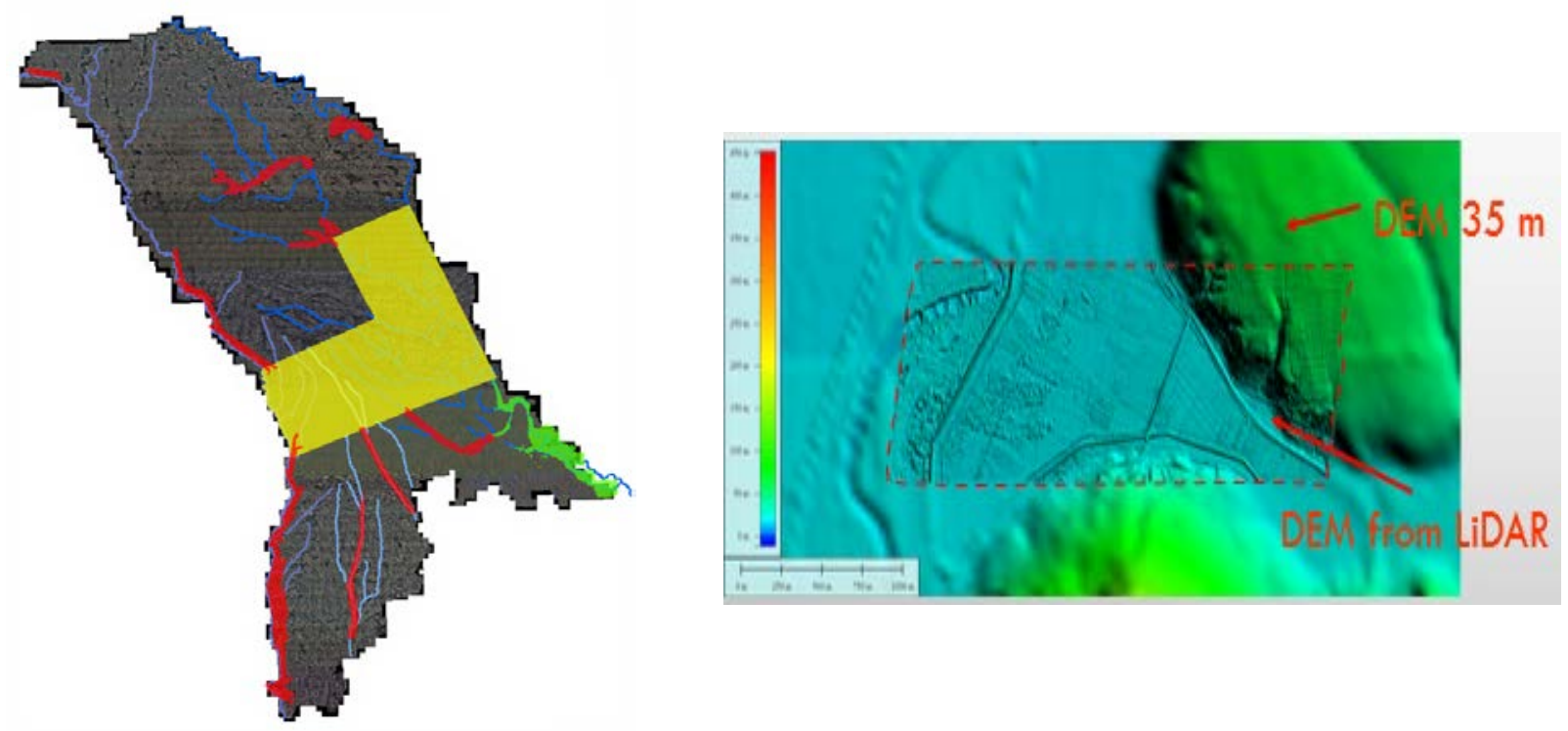

Figure 3. Data collections: Yellow - existing LiDAR survey of the central part of Moldova (2011, ALRC); Red - new LiDAR survey; Green - photogrammetric data derivation. 
The created of the Geodatabase in electronic format containing $[11,12]$ :

- data and information collected,

- high-level flood/risk outlines for whole Moldova,

- maps of hydraulic hazard and risk,

- maps of the flood extension for dam failures,

- river long profiles,

- maps of measures for flood risk reduction,

- gauged flow data on the Dniester and the Prut,

- rainfall runoff analysis for rivers in Moldova,

- models provide flood extent, flood depth and flow velocity,

- calibration and validation using historic flood data (flooded area during 2008 event observed from satellite vs modelled).
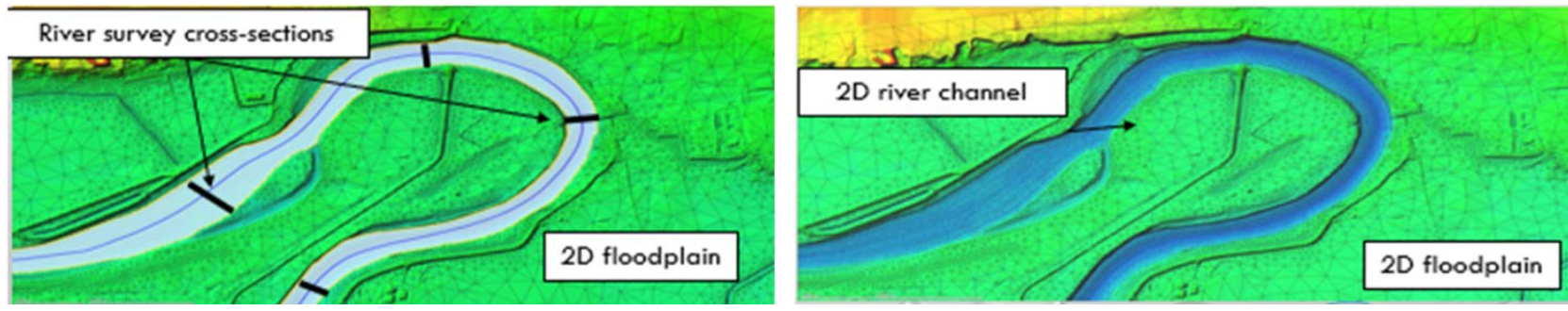

Figure 4. Creation of 1D and 2-dimensional (2D) river and floodplain models.

All these data were taken into account at creation of 1D and 2-dimensional (2D) river and floodplain models (figure 4):

- 1D module solves the equations of De Saint Venant,

- 2D module solves the equations of Navier - Stokes,

- 3 sizes of flood (1\% (1-100-year), $\mathbf{0 . 5 \%}$ (1-200-year), $\mathbf{0 . 1 \%}$ (1-1,000-year) Annual Exceedance.

Model results were provided in GIS format. Flooded areas calculated using a grid of triangular cells (figure 5).
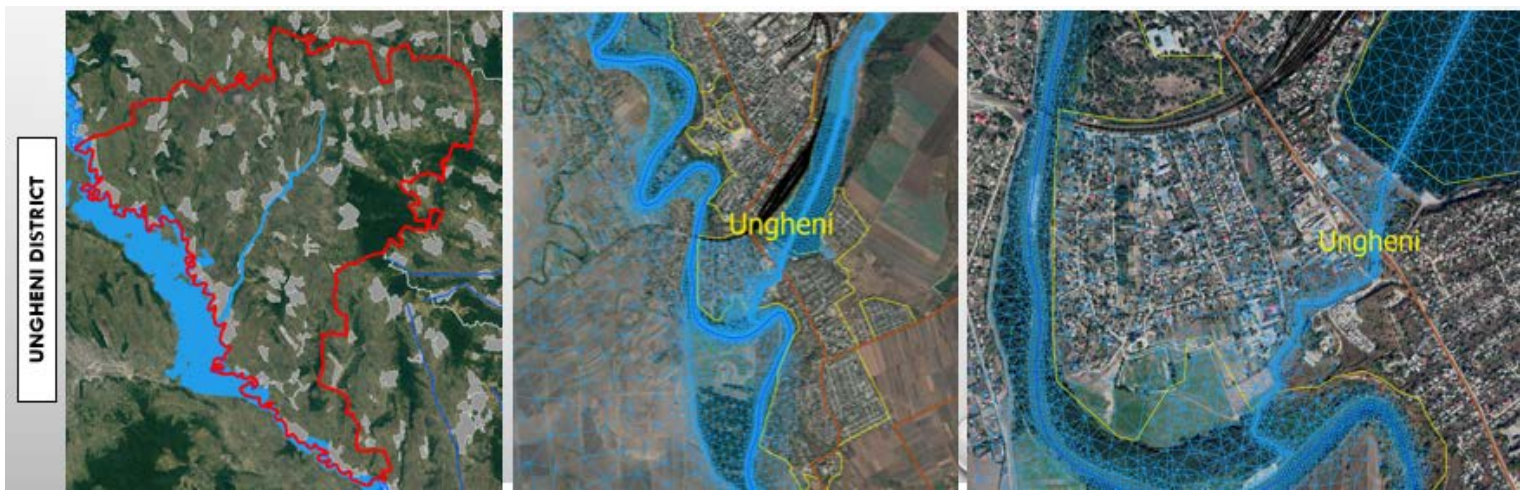

Figure 5. Model Results in GIS format.

Each cell from the grid contains the following values (figure 6):

- area $\left[\mathrm{m}^{2}\right]$,

- ground level [m a.s.l.],

- $\min / \max$ water depth [m],

- water surface elevation [m a.s.l.],

- $\min / \mathrm{max}$ velocity of the water $[\mathrm{m} / \mathrm{s}]$,

- max unit flow during the simulation (depth*speed) $\left[\mathrm{m}^{3}\right]$,

- hazard value (water depth*(velocity+0.5)). 


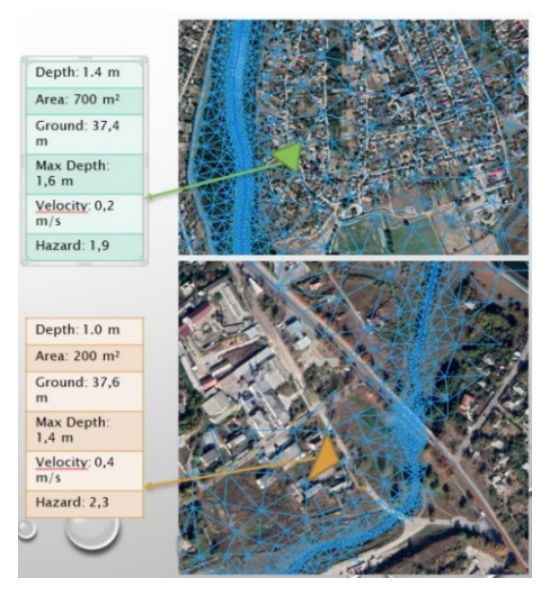

Figure 6. Value of the cells.
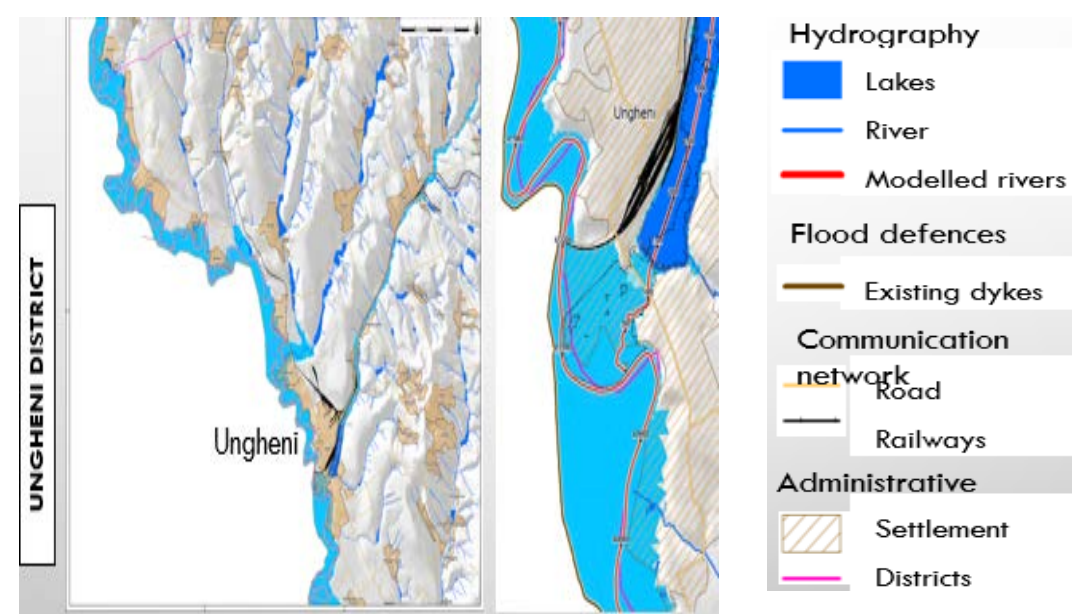

Flood defences

- Existing dykes

Communication network

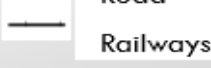

Administrative

Settlement

Districts

Figure 7. Flood hazard in Ungheni district.

Flood hazard mapping with information included within the maps (figure 8) shows us the areas that can be flooded in case of heavy rainfall.

\section{Flood risk assessment}

Purpose of flood risk assessment (FRA) is to estimate the potential adverse consequences of flood scenarios on human health, economic activities and the environment. FRA forms the basis for the identification of flood risk management measures and the preparation of investment programmers [3,7]. The notions 'flood risk' is used to describe the effects of flooding. We defined 'flood risk' as: (the probability of flooding) $x$ (the consequences of flooding (figure 8).

For that purpose, was chosen criteria grouped into 3 main categories (table 2):

- Human impacts,

- Economic impacts,

- Environmental impacts.

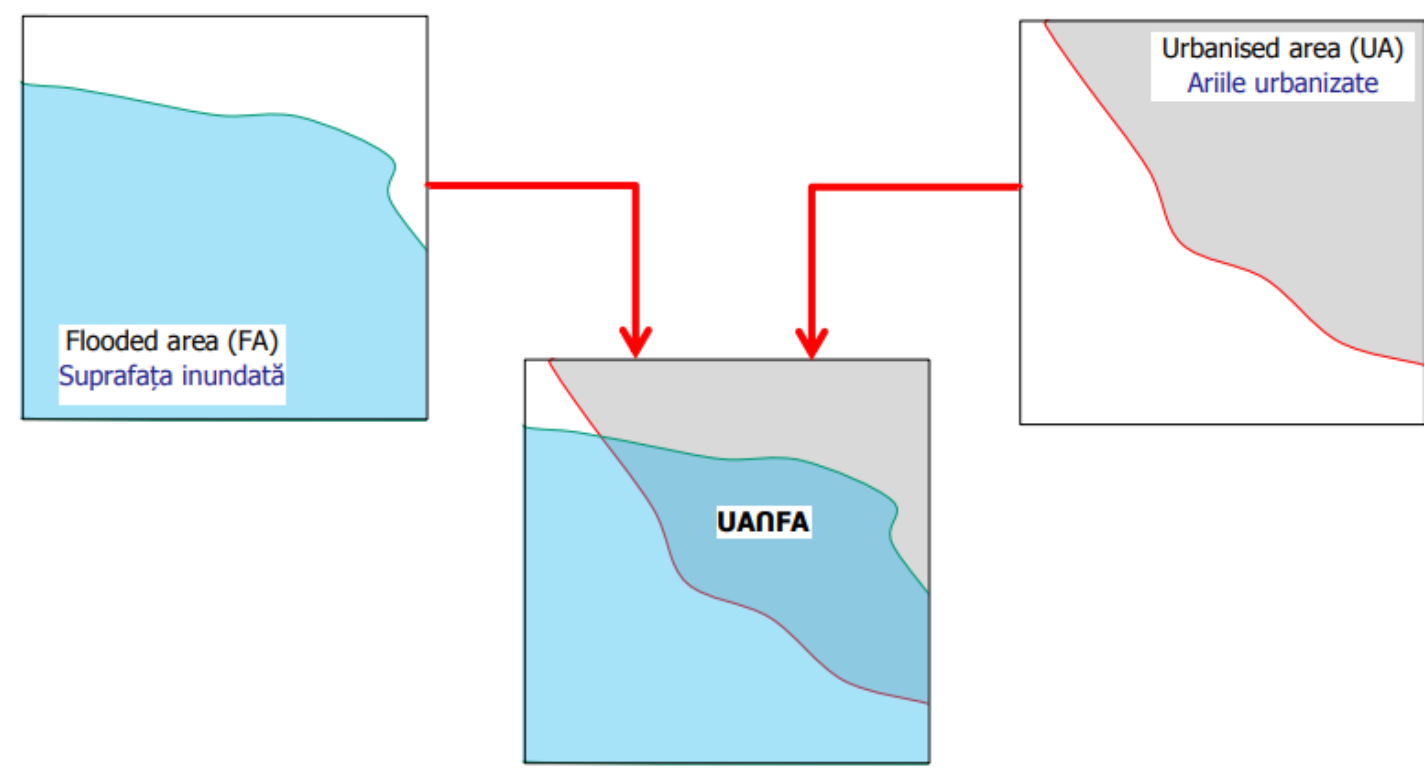

Figure 8. Graphical interpretation of the vulnerability assessment.

Multicriteria analysis of hazard areas based on cartographic materials (GIS thematic layers) and hydraulic models allowed the generation of risk maps. Figure 9 shows the degree of the risk areas (low risk, medium risk, high risk, very high risk) for Ungheni district [9]. 
The criteria unseeing for FRA

\begin{tabular}{|c|c|c|}
\hline $\begin{array}{l}\text { Categories } \\
\text { Categoriile }\end{array}$ & & $\begin{array}{l}\text { Flood risk indicators } \\
\text { Indicatorii riscului de inundații }\end{array}$ \\
\hline \multirow{2}{*}{$\underset{\text { impacts }}{\text { Human }}$} & HU1 & $n^{\circ}$ of affected people \\
\hline & HU2 & $\mathrm{n}^{\circ}$ of severely affected people (combination of depth and velocity > cost) \\
\hline \multirow{3}{*}{$\begin{array}{l}\text { Impact } \\
\text { asupra } \\
\text { Omului }\end{array}$} & HU3 & $n^{\circ}$ of very severely affected people ( $h, v>$ cost, in dam break scenarios) \\
\hline & HU4 & $\mathrm{n}^{\circ}$ of water supply points flooded \\
\hline & HU5 & Length of key infrastructure flooded (main roads, railways) \\
\hline \multirow{3}{*}{$\begin{array}{l}\text { Economic } \\
\text { impacts } \\
\text { Impact } \\
\text { asupra } \\
\text { Economiei }\end{array}$} & EC1 & Damages for residential area (cities, towns, villages) $[€]$ \\
\hline & $\mathrm{EC} 2$ & Damages for non-residential area (industrial and commercial) $[€]$ \\
\hline & EC3 & Agriculture damages $[€]$ \\
\hline \multirow{2}{*}{$\begin{array}{l}\text { Environmen } \\
\text { tal impacts }\end{array}$} & EN1 & Extension of environmental sites flooded $\left[\mathrm{m}^{2}\right]$ \\
\hline & EN2 & $\mathrm{n}^{\circ}$ of heritage sites flooded \\
\hline \multirow{2}{*}{$\begin{array}{l}\text { Impact } \\
\text { asupra } \\
\text { Mediului }\end{array}$} & EN3 & $n^{\circ}$ of pollution sources (WWTP, oil stations, waste disposal sites ...) flooded \\
\hline & EN4 & Extension of diffuse source of pollution $\left[\mathrm{m}^{2}\right]$ \\
\hline
\end{tabular}

Based on the results obtained and the priorities set by the authorities, stakeholders the measures to reduce the risk was identified. Primary objectives agreed with stakeholders was 1) Reduce risk of flooding to people and 2) Reduce risk of flooding of settlements. Thus a range of options have been identified including:

- Structural options for specific areas (e.g. new dykes),

- Non-structural options that could be applied anywhere (e.g. maintenance of dykes),

- Consultation on options to identify the best solutions for stakeholders.

Structural options is mean the raising the standard of protection, so settlements can be protected to the 1 in 100-year standard. Thus can include the follow activities:

- Rehabilitate and improve existing dykes (raising dykes, new dykes (or walls),

- Risk of dyke failure is reduced (improved drainage, Increase flood storage and change the operation of existing dams to reduce flood flows (Costeşti Stânca reservoir), Increase river capacity),

- Options that also enhance the environment (Naturalisation of river channels, Reduce pollution on floodplains).

On this base the structural measures are proposed which consists of new dykes for a total length of $5.0 \mathrm{~km}$ with a height ranging from 1.0 to $3.5 \mathrm{~m}$ and the raising by $1.5 \mathrm{~m}$ of an existing road for a length of $0.5 \mathrm{~km}$ and the dyke height allows a freeboard of $1 \mathrm{~m}$ above the maximum water level for a $1 \%$ flood event (figure 10).

One more example to improve localities protection from flood is via providing more flood storage through modifies Costești-Stânca management rules.

This action was done in the frame of Joint Operational Programme RomaniaRepublic of Moldova 2014-2020, the project „The prevention and protection against floods in the upper Siret and Prut River Basins, through the implementation of a modern monitoring system with automatic stations -EAST AVERT", [10], (figure 11). 


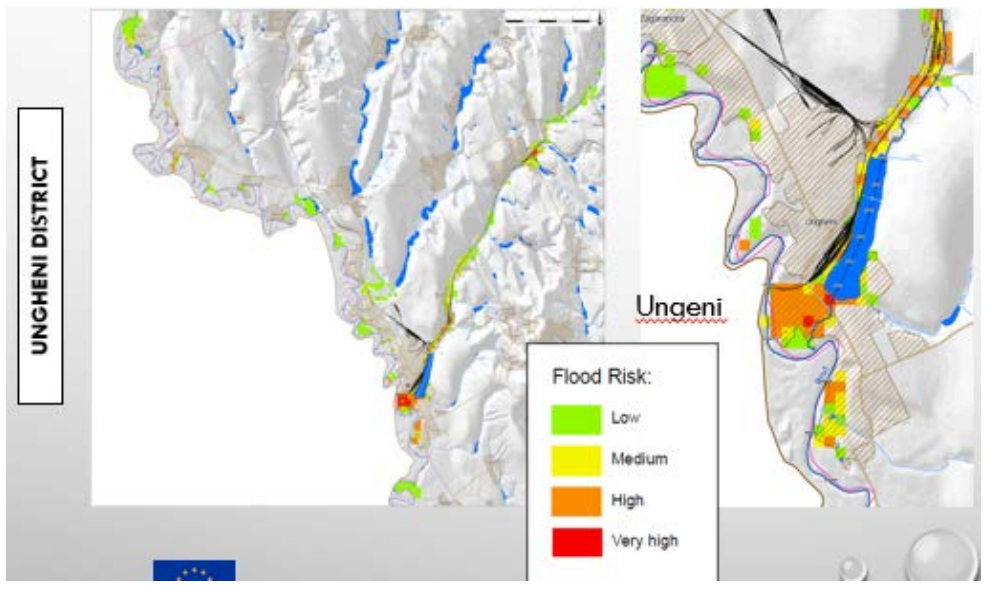

Figure 9. Flood risk maps.
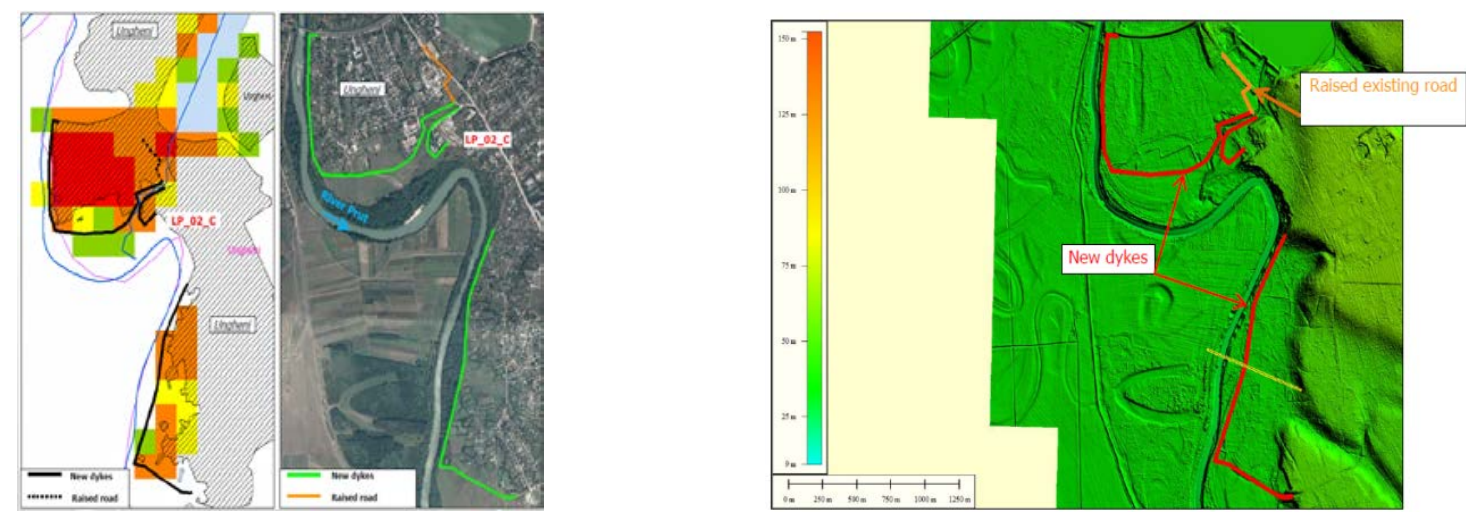

Figure 10. Some structural measures proposed for Ungheni district

One the same time the important role for to reduce the flood risk is via implementation of the non-structural measures which consist in:

- Improving the system of flood management,

- Maintenance,

- Flood warning, preparation and response,

- Land use planning,

- Catchment management (retain soil and floodwater).

The multiple analyses of different kind of measures suggest combinations of options (e.g. Improve dykes + Maintenance of dykes and river channel + Flood forecasting and warning) which are more effective.

One the same time the important role for to reduce the flood risk is via implementation of the non-structural measures which consist in:

- Improving the system of flood management,

- Maintenance,

- Flood warning, preparation and response,

- Land use planning,

- Catchment management (retain soil and floodwater).

The multiple analyses of different kind of measures suggest combinations of options (e.g. Improve dykes + Maintenance of dykes and river channel + Flood forecasting and warning) which are more effective. 


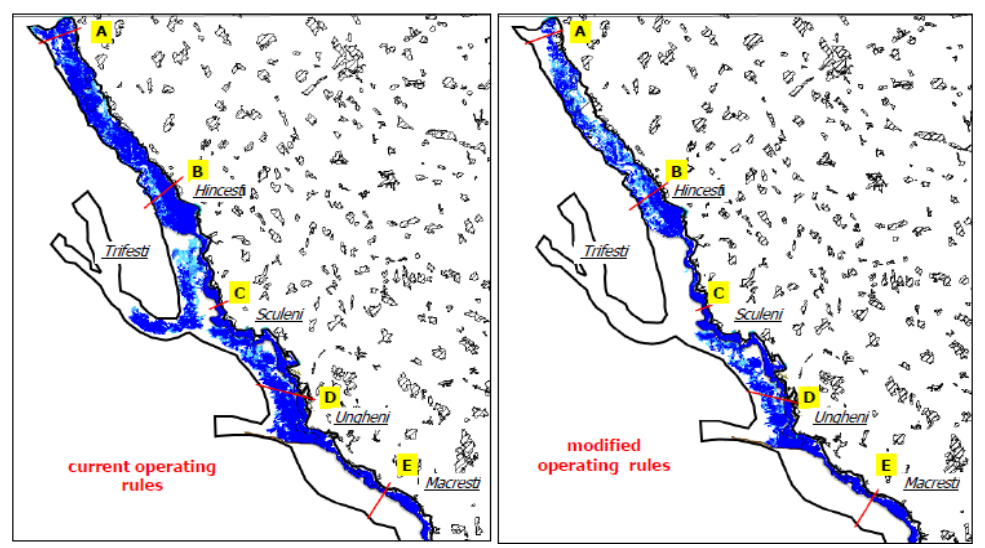

Figure 10. Increasing the flood storage through modifies Costești-Stânca management rules

\section{SWOT analysis as support for measures to reduce the risk}

SWOT analysis can be applied by analyzing and sorting out various things that affect the four factors (Strengths, Weaknesses, Opportunities, Threats). Strengths and Weaknesses are internal factors, while Opportunities and Threats are external factors of people in the community. Strengths and Opportunities have positive impacts, while Weaknesses and Threats have negative impacts for people. In the base of lot of actions and study of materials (reports and social cites) the strengths of people in the study area is:

- Good social networking,

- Own house status,

- Realizing they live in risky area.

And the weaknesses of people in the study area are:

- Low-income people,

- Low education level,

- Old generation,

- Long recovery time after flood,

- Low knowledge on Disaster Risk Reduction,

- Located in flood prone area (geomorphologic aspect),

- Inappropriate drainage system etc.

Opportunities FOR people in the study area:

- Good social networking,

- Good social coping mechanism,

- Realizing they live in risky area,

- Urban development,

- New employment opportunities,

- People awareness on Disaster Risk Reduction is increasing.

Threats for people in the study area:

- Lack of program on Disaster Risk Reduction at catchment level,

- Limited fund on Disaster Risk Reduction,

- Low multi-stakeholders involvement on Disaster Risk Reduction.

As conclusions the preparedness plans and early warning systems is done based on SWOT analysis taking into account strategic aspects. Strategies: Strengths in relation to Threats:

- Encourage social organization on disaster risk reduction, 
- Social approach on land use changing,

- Find alternative funding for disaster risk management.

\section{Strategies: Weaknesses in relation to threats:}

- Preparing emergency preparedness plan,

- Preparing recovery plan,

- Coordination between stakeholders on preparedness, response during flood, and after flood recovery.

Acknowledgments. This publication/material has been produced with the assistance of the European Union. The contents of this publication are the sole responsibility of authors and can in no way be taken to reflect the views of the European Union or of the Joint Operational Programme Romania-Moldova 2014-2020 management structures.

\section{References}

1. EU Floods Directive (FD, 2007/60/EC) on the assessment and management of flood risks. https://eurlex.europa.eu/legal-content/EN/TXT/?uri=celex:32007L0060.

2. Mihailescu C., Clima şi hazardurile Moldovei. Evoluţia, starea, predicţia, Editura „Licorn” S.R.L., Chişinău, 2004.

3. Scorzini A.R., Frank E. - Flood damage curves: new insights from the 2010 flood in Veneto, Italy. Journal of Flood Risk Management. doi: 10.1111/jfr3.12163, 2015.

4. Grama V., A. Avanzi L. Căpățînă, E. Frank, V. Dilan. Flood vulnerability usage for flood risk assessment in the Republic of Moldova., GeoCAD 2016, INTERNATIONAL SCIENTIFIC SYMPOSIUM, Alba Iulia, Romania, May $06-07,2016$.

5. Sochircă E., Căpăţînă L. Evaluarea percepţiei populaţiei a riscurilor la inundaţii în bazinul râului Prut, ACADEMUS, nr. 2 (33), June 2014.

6. Directive 2000/76/EC of the European Parliament and of the Council of 4 December 2000 on the incineration of waste. In: Official Journal of the European Communities [online]. 28.12.2000, L 332/91-L 332/111. [accesat 10.11.2015]. Disponibil:

http://www.central2013.eu/fileadmin/user_upload/Downloads/Document_Centre/OP_

Resources/Incineration_Directive_2000_76.pdf.

7. EPTATF 2013-2016, Management and Technical Assistance Support to Moldova, Flood Protection Project Service contract No TA2011038 MD EST. Disponibil: http://amp.gov.md/contentrepository/ downloadFile.do?uuid=c43f4ff0-e2bd-4ba8-b3d1-95d0a4d.

8. Directive 2000/60/EC of the European Parliament and of the Council of 23 October 2000 establishing a framework for Community action in the field of water policy. Disponible: ELI: http://data.europa.eu/eli/dir/2000/60/oj

9. G.D. Nr. (HG) 562/2020 din 31.07.2020, on the approval of Flood Risk Management Plans. https://www.legis.md/cautare/getResults?doc_id=122775\&lang=ro

10. Joint Operational Programme Romania-Republic of Moldova 2014-2020, the project „The prevention and protection against floods in the upper Siret and Prut River Basins, through the implementation of a modern monitoring system with automatic stations -EAST AVERT", Disponibil: https://keep.eu/projects/15262/The-prevention-and-protecti-ENI.

11. Albano R., Sole1 A., Adamowski J., Mancusi L. FloodRisk: a collaborative, free and open-source software for flood risk analysis. Downloaded by [191.101.100.25] at 11:50 29 October 2017.

12. Grama V. M. Turculeț A. Iacovlev V. Bujac A. Tăbăcaru. Using the Web GIS application for managing the abstraction and discharge water points in a river basin. European Geosciences Union General Assembly 2017. Vienna, Austria, 23-28 Aprilie 2017. 